\title{
SEDENTARY AND DYNAMIC ACTIVITIES OF ADOLESCENTS AS PREDICTIONS OF POSTURAL STATUS
}

\author{
Dijana Lastro, Olivera Pilipovic Spasojevic \\ Institute for Physical Medicine and Rehabilitation "Dr Miroslav Zotović" in Banja Luka, Faculty of Medicine University of \\ Banja Luka, Banja Luka, Republic of Srpska, Bosnia and Herzegovina

\section{SEDENTARNE I DINAMIČKE AKTIVNOSTI ADOLESCENATA KAO PREDIKTORI POSTURALNOG STATUSA}

\author{
Dijana Laštro, Olivera Pilipović-Spasojević \\ Zavod za fizikalnu medicinu i rehabilitaciju "dr Miroslav Zotović" u Banja Luci, Medicinski fakultet Univerziteta u Banjoj \\ Luci, Banja Luka, Republika Srpska, Bosna i Hercegovina
}

\section{ABSTRACT}

Objective. Body posture is a habit of motor skills upgraded to a specific morphological and functional base. During the period of an adolescent's growth and development, sedentary habits and physical activity are important factors of body posture. The aim of this work was to find out which type of activity, sedentary, dynamic or both, influence the body posture of senior elementary school children.

Methods. This prospective study involved 120 examinees aged 10 to 16 of both genders, divided into three groups. The first group consisted of 40 sport active children. The second group consisted of 40 non-sport active children, and the third group of 40 children who had a deformity of spine. The authorized test for body posture, Physical Activity Evaluation Test for elementary school children (TFA) and Body Mass Index (BMI) were used.

Results. None of the children had excellent body posture. Very good and good body posture grade was present in 77.5 $\%, 50 \%$ and $35 \%$ of children in groups 1, 2 and 3, respectively. Significant correlation has been established between the body posture of the monitored groups on one side and the dynamic activities $(p=0.000)$, and TFA on the other $(p=0.000)$, which was not the case with the sedentary activities $(p=0.315)$.

Conclusion. Contrary to the expected, the results showed that the dynamic activities had more important influence on body posture in each category of children, when compared to sedentary activities. Urgent interventions in preventive health policy are needed to promote physical activity among adolescents.

Key words: posture; life style; adolescent.

\section{INTRODUCTION}

Body posture is a habit of motor activities upgraded to a specific morphological and functional base. It represents a manifestation of physical and psychological status of an individual. In a kinetic sense, it is an indicator of mechanical efficiency, equally as muscle balance and neuromuscular coordination. During the whole life,

\section{SAŽETAK}

Cilj. Držanje tijela je navika motornih aktivnosti nadograđena na određenu morfološku $i$ funkcionalnu osnovu. U periodu rasta i razvoja adolescenta, sedentarne navike i fizička aktivnost su bitni faktori držanja tijela. Cilj ovog rada bio je da se ustanovi koja vrsta aktivnosti sedentarna, dinamička ili obe - ima uticaj na držanja tijela kod djece koja pohađaju starije razrede osnovne škole.

Metode. Urađena je prospektivna studija sa 120 ispitanika grupisanih u tri grupe, uzrasta od 10 do 16 godina, sa jednakim učešćem pripadnika oba pola. Prvu grupu činilo je 40 djece koja se aktivno bave sportom. Drugu grupu činilo je 40 djece koja se ne bave aktivno sportom, a treću grupu 40 djece koja imaju deformitet kičmenog stuba. Za potrebe istraživanja koristili smo autorizovani test za ocjenu držanja tijela (TDT), test procjene stepena fizičke aktivnosti za djecu školskog uzrasta (TFA) i Body mass index (BMI).

Rezultati. U odnosu na svaki kategorički definisani uzorak, ocjenu odličnog držanja tijela nije imalo nijedno dijete. U prvoj grupi, ocjenu vrlo dobrog i dobrog držanja imalo je 77,5\%, u drugoj grupi 50\%, a u trećoj 35\% djece. Ustanovljena je statistička značajnost između držanja tijela posmatranih grupa, dinamičkih aktivnosti $(p=0,000)$ i TFA ukupnog skora $(p=0,000)$, što nije bilo slučaj sa sedentarnim aktivnostima ( $p=0,315)$.

Zaključak. Suprotno od očekivanog, rezultati su pokazali da su dinamičke aktivnosti imale veći uticaj na držanje tijela za svaki kategorički definisani uzorak od sedentarnih aktivnosti. Potrebne su hitne intervencije koje imaju za cilj da promovišu fizičku aktivnost među adolescentima kroz razvoj preventivne zdravstvene politike.

Ključne riječi: držanje tijela; stil življenja; adolescent.

human body posture is subject to change (1-4). This is mostly visible during the period of growth and development of children. Rapid changes of the environment, sedentary style of life, limitations in physical activity and inadequate eating habits are inseparable from the civilization progress (5-8). In spite of 
the development of the protective-adaptive mechanisms, human body is not able to adjust to dynamic changes of modern life style, which inevitably leads to bad body posture patterns. The look of the body and the condition of locomotor system in the phase of childhood and adolescence depends on the activity and forced position that young individuals frequently keep longer due to school attendance and interactions with the surroundings (9-12). With staying longer in a sitting position (and usually there is an impression that it is an inadequate position) on inappropriate furniture, there is a rising tendency of favouring sedentary way of life that may result in postural changes $(13,14)$. Besides, it is assumed that postural habits adopted in childhood and adolescence will continue in the adult age (8). Used to mainly static activities as usual causes of spinal changes of young men and women, a question arises to what extent and which activity of an adolescent is connected to the body posture. The aim of the present research was to find out which type of activity - sedentary, dynamic or both of them - have influence on body posture of senior elementary school children through tasks by which the differences in body posture, Body Mass Index (BMI) and physical activity would be established among the three categorised groups of children along with finding the causative-consequential correlation between sedentary, dynamic activities and body posture for each group of subjects.

\section{PATIENTS AND METHODS}

This prospective study involved a total of 120 subjects aged 10 to 16 . The subjects were allocated into three groups with the same number of boys and girls, which was accomplished by means of the block randomization method. The first group involved 40 children who were actively engaged in swimming and who were members of the Swimming Club "Olimp" Banja Luka. The second group involved children who were not actively engaged in sport and were regular pupils of the Elementary School "Zmaj Jova Jovanović" in Banja Luka, and the third group consisted of children who were sent for rehabilitation treatment to the Institute for Physical Medicine and Rehabilitation "Dr Miroslav Zotović" Banja Luka.

The Ethics Committee of the Institute of Physical Medicine and Rehabilitation, the Board of the swimming club "Olimp" and the Board of Elementary School "Zmaj Jova Jovanovic", approved the conduct of this research, the use of instruments and adequate space in order to provide conditions for its implementation in order to protect the privacy of children as well as objective testing conditions. After a specific explanation of the research for parents and children, every child had consent signed by his/her parent to voluntarily participate in the research before entering the test.

\section{Inclusion criteria}

Group 1: senior elementary school children aged 1016 , both genders, active members of the Swimming Club “Olimp" Banja Luka. Group 2: senior elementary school children age 10-16, both genders, not active in sport, regular pupils of Elementary School, "Zmaj Jova Jovanović", Banja Luka. Group 3: senior elementary school children, age 10-16, both genders, sent to rehabilitation treatment in The Institution for Physical Medicine and Rehabilitation "Dr Miroslav Zotović", Banja Luka with functional diagnosis Scoliosis vertebrae thoracolumbalis verified by the physiatrist in charge.

\section{Exclusion criteria}

The non-exclusion criterion was created on the basis of Group 3 whose Occupational therapist's health records had exclusively the diagnosis of scoliosis vertebrae thoracolmbalis without other follow-up diagnosis, and based on that, we sorted criteria that excluded any cognitive, locomotor and other disability or deformity in children of Group 1 and Group 2, which the teacher of physical education and the coach selected, based on the data of the systematic review. So, children did not have a medical chart of illness such as neurological and muscle diseases, conditions after trauma of locomotor system, endocrinopathy, skeletal dysplasia or chondrodysplasia, diseases of connective tissue, mental retardation, metabolic disturbances of bones, congenital musculoskeletal deformities, children in whose history the steroid therapy has been recorded, conditions after surgical treatment of scoliosis, children with applied chest and spinal orthosis.

\section{Research instruments}

In this research we used the self-assessment of physical activity for children (AFA), the authorized Body Posture Test (TDT) and Body Mass Index (BMI). The respondents were tested in groups by the same person and in the presence of parents/guardians with the same group of tests. The survey was conducted by a researcher by asking individual questions to which the children gave answers in consultation with their parents. All the children were tested by AFA that included data regarding the level of time spent studying, sedentary screen-based activities (video gaming, computer science), physical education classes, corrective exercises, playing games (time spent outside), sports activities, training, warming up before training and walking (15).

Testing the degree of physical activity for school-age children was conducted in the form of a survey. The answers were graded from 0 to 4 , which signifies moving from better to worse (grade 0 is excellent, and grade 4 is bad). From the entire AFA we singled out 8 items, grouping them into two separate entities - one reflecting 
sedentary activities (time spent at school desk, time spent studying, time spent in front of a computer), and the second, reflecting dynamic activities during the day (playing with mates outdoors, sport activities, regular training, warming-up exercises for training, walking). Alpha Krombach's measure of reliability scale for the observed two entities in relation to the total score was 0.67, which presents a moderately satisfying compatibility.

For evaluation of body posture, the method of Volanski was used (16). This method includes the following body segments: holding of head, holding of shoulders, shape of thorax, holding of blades, lateral curves of the spinal scoliosis, holding of the anterior abdominal wall, shape of legs and arch of feet. All eight segments have been evaluated for each subject on a three-degree scale, and the obtained sum was indicator of body posture. Volanski recommended the differentiation of sum on the following five-degree scale: 0 points - excellent body posture, 1 to 4 points - very good body posture, 5 to 8 points - good posture, 9 to 12 points - bad posture, 13 to 16 points - very bad posture. Krombach's reliability of the Body Posture Test in the total sample was 0.43 .

Testing of body posture was carried out depending on the defined sample (before the beginning of physical education class, before the beginning of training and before the beginning of kinesitherapy exercises and working therapy) and place (cabinet of physical education teacher, cabinet of swimming club, working therapy space). All spaces were well lit and heated in order to enable longer stay at work. The subjects were tested in groups by the same researcher and always with the same group of tests. Self-assessment of physical activity of children AFA was performed by the researcher in form of an interview, whereas Body Posture Test was carried out by means of the observation method with the consent and presence of the parents, the teacher of physical education and/ or the coach. Body posture was assessed according to the requirements of the standard protocol.

$\mathrm{BMI}$ is the simple index representing the ratio of body mass and body height and is mainly used for classification of excessive body mass and obesity. BMI is calculated in the same way in children, adolescents and adults, but the interpretation of the obtained values is different for two reasons: a) the amount of fat in body is subject to change with age and $b$ ) the amount of fat in girls and boys differs (17).

For statistical data processing programms MO Excel and SPSS for Windows have been used. In this research the following statistical procedures were used: descriptive statistics, $\chi^{2}$-test, Kruskal-Wallis test and Mann-Whitney test of multiple comparisons.

\section{RESULTS}

Analysis of subjects according to age

Within the complete specimen of 120 children, with an equal percentage presence of boys and girls in all three groups, there was no statistical significance regarding age structure of subjects, as indicated in Table 1.

Analyses of subjects regarding body posture test

Table 1. Age of children per group

\begin{tabular}{|l|l|l|l|l|l|l|}
\hline & $\begin{array}{l}1^{\text {st }} \\
\text { group }\end{array}$ & $\begin{array}{l}2^{\text {nd }} \\
\text { group }\end{array}$ & $\begin{array}{l}3^{\text {rd }} \\
\text { group }\end{array}$ & Boys & Girls & Total \\
\hline Mean & 13.22 & 13.77 & 13.08 & 13.52 & 13.03 & 13.36 \\
\hline SD & 1.86 & 1.27 & 1,99 & 1.93 & 1.50 & 1.75 \\
\hline
\end{tabular}

Legend: 1 - children who are active in sports,

2 - children who are not involved in sports,

3 - children with verified diagnosis

scoliosis vertebrae thoracolumbalis.

Each group consisted of 40 examinees.

In Table 2. Descriptive statistical analysis of the Body Posture Test results in observed groups and the total sample of school-age children is presented. Body posture test monitors eight variables, the sum of which gives the total test score. Body posture grade is better if its arithmetic mean is lower. Differences in body posture among the three groups of children have been analysed by the Kruskal-Wallis test. There was a statistically significant difference in posture variables: head $(p=0.014)$, shoulders $(p=0.03)$, blades $(p=0.030)$, feet $(p=0.000)$, along with the total body posture grade $(p=0.000)$. Comparing each pair separately and all the combinations of pairs (groups) statistical significance was found and presented in Table 3.

Table 2. Descriptive analysis of the sample by Body Posture Test (TDT)

\begin{tabular}{|l|l|l|l|l|}
\hline & $1^{\text {st }}$ group & $2^{\text {nd }}$ group & $3^{\text {rd }}$ group & Total \\
\hline Mean & 7.13 & 8.27 & 9.23 & 8.21 \\
\hline SD & 2.053 & 1.96 & 2.02 & 2.173 \\
\hline
\end{tabular}

Legend: 1 - children who are active in sports,

2 - children who are not involved in sports,

3 - children with verified diagnosis

scoliosis vertebrae thoracolumbalis.

Each group consisted of 40 subjects.

Based on Table 3, significant differences were found in:

the position of head holding in favor of children who are actively engaged in sport activities, with the average score of 1.58, compared to children who are not actively engaged in sport (1.77) and children with verified deformities (1.85).

- the position of holding shoulders in favor of children who are actively engaged in sport activities (1.40), compared to children diagnosed with Scoliosis vertebrae thoracolumbalis (1.60). 
Table 3. Differences in posture between the three categorically defined samples (Mann-Whitney's multiple comparison test)

\begin{tabular}{|l|l|l|}
\hline \multicolumn{1}{|c|}{ Variables } & $\begin{array}{l}\text { Groups of } \\
\text { children }\end{array}$ & $\mathrm{P}$ \\
\hline \multirow{4}{*}{ TDT1- head posture } & $1-2$ & 0.40 \\
\cline { 2 - 3 } & $1-3$ & $0.007^{* *}$ \\
\cline { 2 - 3 } & $2-3$ & 0.530 \\
\hline \multirow{4}{*}{$\begin{array}{l}\text { TDT 2- keeping the } \\
\text { shoulders }\end{array}$} & $1-2$ & 0.318 \\
\cline { 2 - 3 } & $1-3$ & 0.102 \\
\cline { 2 - 3 } & $2-3$ & $0.009^{* *}$ \\
\hline \multirow{4}{*}{ TDT 4 - holding blades } & $1-2$ & 0.726 \\
\cline { 2 - 3 } & $1-3$ & $0.04^{*}$ \\
\cline { 2 - 3 } & $2-3$ & $0.01^{*}$ \\
\hline TDT8 - keeping feet & $1-2$ & $0.000^{* *}$ \\
\cline { 2 - 3 } & $1-3$ & $0.000^{* *}$ \\
\cline { 2 - 3 } & $2-3$ & 0.326 \\
\hline \multirow{5}{*}{ TDT Total score } & $1-2$ & $0.009^{* *}$ \\
\cline { 2 - 3 } & $1-3$ & $0.000^{* *}$ \\
\cline { 2 - 3 } & $2-3$ & \\
\hline
\end{tabular}

Legend: 1 - children who are active in sports,

2 - children who are not involved in sports,

3 - children with verified diagnosis

scoliosis vertebrae thoracolumbalis.

Each group consisted of 40 subjects.

* Significance level of statistical test 0.05 ;

** Significance statistical test level of 0.001
- the position of holding blades in favor of children who are not actively engaged in sport activities (0.80), compared to children who are actively engaged in sport activities (0.85) and children with the verified diagnosis Scoliosis vertebrae thoracolumbalis (1.10)

- the position of holding feet in favor of children who are are actively engaged in sport activities (0.72) in relation to children who are not actively engaged in sport activities (1.53), and children who have diagnosis of Scoliosis vertebrae thoracolumbalis (1.35).

Statistically significant difference exists in total grade for body posture in favor of children who are actively engaged in sport activities (7.13), as compared to children who are not actively engaged in sport activities (8.27) and children with verified diagnosis Scoliosis vertebrae thoracolumbalis (9.23).

Differentiation of body posture test score and relations among the three defined groups are shown in Table 4.

The obtained value of the Pearson coefficient (17.596) is less than the borderline value for specific amount of freedom and significance level of $p=0.004$, which indicates an important correlation among all three groups of school-age children regarding to body posture test category. None of the children had excellent body posture. $72.5 \%$ of children who were actively engaged in sport activities had very good and good posture, as well as 50\% of children who were not actively engaged in sport activities and only $35 \%$ of children with verified scoliosis.

Table 4. Relation between the groups of school children and Body Posture Test (TDT) ( $\chi^{2}$ test)

\begin{tabular}{|c|c|c|c|c|c|c|}
\hline & & \multicolumn{4}{|c|}{ TDT-categories } & \multirow[t]{2}{*}{ Total } \\
\hline & & $\begin{array}{l}\text { very } \\
\text { good } \\
\text { posture }\end{array}$ & $\begin{array}{l}\text { good } \\
\text { posture }\end{array}$ & $\begin{array}{l}\text { poor } \\
\text { posture }\end{array}$ & $\begin{array}{l}\text { very } \\
\text { poor } \\
\text { posture }\end{array}$ & \\
\hline \multirow[t]{2}{*}{$1^{\text {st }}$ group } & $\begin{array}{l}\text { The total number of the examinees in the } \\
\text { group in relation to categories }\end{array}$ & 4 & 25 & 11 & 0 & 40 \\
\hline & $\%$ in relation to the TDT & $10 \%$ & $62.5 \%$ & $27.5 \%$ & $0.0 \%$ & $100 \%$ \\
\hline \multirow[t]{2}{*}{$2^{\text {nd }}$ group } & $\begin{array}{l}\text { The total number of the examinees in the } \\
\text { group in relation to categories }\end{array}$ & 2 & 18 & 20 & 0 & 40 \\
\hline & $\%$ in relation to the $\mathrm{TDT}$ & $5 \%$ & $45 \%$ & $50 \%$ & $0 \%$ & $100 \%$ \\
\hline \multirow[t]{2}{*}{$3^{\text {rd }}$ group } & $\begin{array}{l}\text { The total number of the examinees in the } \\
\text { group in relation to categories }\end{array}$ & 0 & 14 & 23 & 3 & 40 \\
\hline & $\%$ in relation to the TDT & $0 \%$ & $35 \%$ & $57.5 \%$ & $7.5 \%$ & $100 \%$ \\
\hline \multirow[t]{2}{*}{ Total } & $\begin{array}{l}\text { The total number of the examinees in the } \\
\text { group in relation to categories }\end{array}$ & 6 & 57 & 54 & 3 & 120 \\
\hline & $\%$ in relation to the TDT & $5 \%$ & $47.5 \%$ & $45 \%$ & $2.5 \%$ & $100 \%$ \\
\hline
\end{tabular}

Legend: 1 - children who are active in sports, 2 - children who are not involved in sports,

3 - children with verified diagnosis scoliosis vertebrae thoracolumbalis.

Each group consisted of 40 subjects. 
Analysis of subjects according to BMI

For evaluation of BMI, parameters of body weight and body height were used and the BMI formula for age 2 to 20 was utilised. In Table 5, descriptive analyses of BMI in observed groups is shown, but also for all children. It was found, based on Kruskal-Wallis test, that the difference in obtained values of the continuos dependent variable among the three groups of children was significant $\left(\chi^{2}\right.$ $=13.66, p=0.00)$. Group of school children who are not actively engaged in sport activities had considerably higher BMI (20.42) than both the group actively engaged in sport activities (18.21) and the group of children with verified scoliosis (18.23). In order to indicate the difference, Mann-Whitney test of multiple comparison was done as showed in Table 6. According to the MannWhitney test, statistical significance was found when comparing the first versus the second group ( $p=0.007)$, and the second verus the third group $(p=0.000)$.

Analysis of subjects according to the self-assessment of physical activity of children (AFA)

For evaluation of physical activity for school-age children according the AFA (which involves nineteen items) was used. The interpretation of the differences in assesment was done in the following way: the bigger the average value, the bigger expressiveness of the tested item is. Kruskal-Wallis test establishes the difference for nineteen items observed by AFA, but statistical significance was noticed only in nine variables: success in

Table 5. Descriptive analysis of the sample according to Body Mass Index (BMI)

\begin{tabular}{|l|l|l|l|l|}
\hline & $1^{\text {st }}$ group & $2^{\text {nd }}$ group & $3^{\text {rd }}$ group & Total \\
\hline Mean & 19.06 & 20.85 & 18.25 & 19.39 \\
\hline SD & 2.92 & 3.25 & 2.57 & 3.10 \\
\hline
\end{tabular}

Legend: 1 - children who are active in sports,

2 - children who are not involved in sports,

3 - children with verified diagnosis

scoliosis vertebrae thoracolumbalis.

Each group consisted of 40 subjects.

Table 6. Differences in Body Mass Index between the three groups of school childern (Mann-Whitney's multiple comparison test)

\begin{tabular}{|l|l|l|}
\hline Variables & $\begin{array}{l}\text { Groups of } \\
\text { children }\end{array}$ & $\mathrm{P}$ \\
\hline Body mas index & $1-2$ & $0.007 * *$ \\
\cline { 2 - 3 } & $1-3$ & 0.485 \\
\cline { 2 - 3 } & $2-3$ & $0.000^{* *}$ \\
\hline
\end{tabular}

Legend: 1 - children who are active in sports,

2 - children who are not involved in sports,

3 - children with verified diagnosis

scoliosis vertebrae thoracolumbalis.

Each group consisted of 40 subjects. school, engagement in sport acyivities, regular training, warming-up exercises for training, walking, appetite, verified bad posture and presence of thorax deformity.

Some AFA items were singled out and grouped into subscores, that is in two separate entities, one concentrating on sedentary - static activities (time spent at school desks, time spent in studying and time spent in front of a computer) and the dynamic activity of children during the day (free playing outdoors with mates, the length of training sport, regular training, regularity and the length of warming-up exercises before training, walking during the day). In Table 7 statistically significant differences are noticed in static and dynamic activities and the total AFA scores are shown. Therefore, it is necessary to compare separately and all combinations of pairs showed in Table 8 by using Mann-Whitney test of multiple pairs comparison.

Table 7. Sedentary, dynamic activity and AFA total score in the three groups of school children

\begin{tabular}{|l|l|l|l|}
\hline \multicolumn{1}{|c|}{ Variables } & $\begin{array}{l}\text { Groups of } \\
\text { children }\end{array}$ & $\mathrm{M}$ & $\mathrm{SD}$ \\
\hline \multirow{5}{*}{ AFA sedentary } & 1 & 7.75 & 1.50 \\
\cline { 2 - 4 } & 2 & 7.30 & 1.24 \\
\cline { 2 - 4 } & 3 & 7.68 & 1,54 \\
\cline { 2 - 4 } & Total & 7.57 & 1.44 \\
\hline AFA dynamic & 1 & 18.47 & 1.81 \\
\cline { 2 - 4 } & 2 & 6.13 & 1.70 \\
\cline { 2 - 4 } & 3 & 14.75 & 5.94 \\
\cline { 2 - 4 } & Total & 13.12 & 6.37 \\
\hline \multirow{5}{*}{ AFA total } & 1 & 64.93 & 5.30 \\
\cline { 2 - 4 } & 2 & 53.53 & 4.96 \\
\cline { 2 - 4 } & 3 & 56.03 & 8.02 \\
\cline { 2 - 4 } & Total & 58.16 & 7.90 \\
\hline
\end{tabular}

Legend: 1 - children who are active in sports,

2 - children who are not involved in sports,

3 - children with verified diagnosis

scoliosis vertebrae thoracolumbalis.

Each group consisted of 40 subjects.

Table 8. Differences in the degree of self-assessment of physical activity among the three groups of school children (multiple comparison test-Mann-Whitney test)

\begin{tabular}{|l|l|l|}
\hline Variables & $\begin{array}{l}\text { Groups } \\
\text { of children }\end{array}$ & $\mathrm{P}$ \\
\hline \multirow{3}{*}{ AFA dynamic } & $1-2$ & 0.000 \\
\cline { 2 - 3 } & $1-3$ & 0.033 \\
\cline { 2 - 3 } & $2-3$ & 0.000 \\
\hline \multirow{3}{*}{ AFA total } & $1-2$ & 0.000 \\
\cline { 2 - 3 } & $1-3$ & 0.000 \\
\cline { 2 - 3 } & $2-3$ & 0.045 \\
\hline
\end{tabular}

Legend: 1 - children who are active in sports,

2 - children who are not involved in sports,

3 - children with verified diagnosis

scoliosis vertebrae thoracolumbalis.

Each group consisted of 40 subjects. 
Comparison of the differences in dynamic activities favoured the children who are actively engaged in sport acttivities (18.47) compared to children who are not actively engaged in sport activities (6.13), as well as the children who had verified scoliosis (14.75) compared to children not actively engaged in sport activities (6.13). The total score of static and dynamic activities indicates statistically significant difference in favour of children who are actively engaged in sport activities (64.93) compared to children who are not actively engaged in sport activities (53.53), and to children who have verified scoliosis of spine (56.03).

\section{DISCUSSION}

Normal body posture is a relative term. No doubt, it has been under the significant influence of statics and the human functioning dynamics, whereas it is known that healthy lifestyle including the normal posture depends on numerous surrounding factors, physical activity and eating habits (18-20). The study was aimed at establishing which kind of activity - sedentary, dynamic or both - affect the body posture of older elementary school-age children.

A statistically relevant difference in postural variables related to body posture was confirmed by Jandrić (2016), which compared the differences in postural disorders in a sample of 150 adolescents, $13.2+/-1.34$ years of age who were training handball and their non-training peers and found that there were no differences between these two samples compared to scoliosis, kifos and pes varus ( $\mathrm{p}>$ 0.05) (21). Research conducted by Medojević and Jakšić (2007), indicated that there was a significant difference in body posture in children (22). Jovović and Čanjak (2012) carried out the research on the sample of 315 subjects, out of which 160 boys and 155 girls, average age of 13.6. The research programme involved students from 23 elementary schools from different socio-economic environments in Montenegro. It was found that the majority of subjects had impaired spinal and blades status, deviation of lower limbs ("O" legs) and flat feet (23). In the present study, although the assessments TDT had a five-degree scale, there were no children with an "excellent posture", regardless of sedentary or dynamic influence on groups. A total of $28.5 \%$ children actively engaged in sport had poor and bad posture, as well as 50\% of children who were not actively engaged in sport and $65 \%$ of children with verified scoliosis of the spinal column.

The group of children not actively engaged in sport had bigger BMI than the group of children actively engaged in sport and also bigger than in children with verified scoliosis. Despite the existence of statistically significant differences, it must be stressed that BMI found is normal for the age we measured - score of $18 \mathrm{BMI}$ is classified as normal for the age we measured - it is classified as normal finding according to reference values for age and gender suggested by WHO (24). Nevertheless, there is an evident difference between the children who are not actively engaged in sport in comparison to the other groups. It is assumed that these children are more prone to obesity. It is particularly interesting that the majority of researches dealing with nutritive habits of adolescents indicated the increased body mass that additionally impaired body posture and school-age children activity (25-27). One medical check-up found the opposite proofs for correlation between sedentary activities and BMI. At the same time, a moderate proof was found for negative correlation between sedentary and dynamic activities (2728). Brandalize and Leite (2010) showed that obesity may cause anterior displacement of the gravity centre, causing adaptation within spinal column and lower limbs. Such adaptations may become permanent, causing postural deviations, like lumbar hyperlordosis with an increased compensational back kyphosis, cervical hyperlordosis and head anteriorization. On lower limbs, pelvic anteversion may occur, connected with internal hips rotation, knee valgus and flat feet (29). At the same time, Martelli i Traebert (2004) reported that children with low body weight might have even higher frequency of postural deviation, connected with inadequate school furniture, student's growth phase and the time spent in school (30), which has been confirmed by the present research.

It was observed that statistical significance among the groups could not been found with sedentary, but with dynamic activity. Dynamic score AFA showed expectedly higher score within the group of sport active children (18.47), and to certain extent, a high score was surprising in children with verified spine scoliosis (14.75), related to the non-sport active children whose dynamic AFA score was convincingly the lowest (6.13). Such a result could be explained by the fact that children with verified scoliosis were on a comprehensive rehabilitation treatment. The treatment included kinesitherapy and work therapy that gave to the that group of children some experience and values of purposful activities in everyday life, which justified higher result of the dynamic score. The group of children who were not doing any sport had poor and bad posture in $50 \%$ of cases along with the same very low dynamic score values, which is an alarm for undertaking adequate preventive measures. In the study evaluating students from the first to the fourth grade of one primary school in Brazil, some asymetries and postural changes were reported at $98 \%$ of individuals (31). In another study of Brazilian school age children, the correlation between present scoliosis and physical activity was found (32). It is important to stress that all mentioned studies evaluated external postural changes and that non-invasive methods have been used, like in our study. Since there is an evident 
decrease in physical activity during the period of adolescence (33), and that the young people spend a lot of time both at home and in school sedentary $(34,35)$, certain necessary interventions aimed at promoting physical activity among adolescents are urgently warranted.

Therefore, it can be concluded that sedentary habits may be related to postural changes, but not necessarily, whereas dynamic activities physiologically and morphologically build a body enabling proper posture and reduce the occurence of bad postural habits leading to deformities of spine during the period of growth and development. It is necessary to motivate the conscience of children, parents, with particular acceleration of preventive medicine policy development.

\section{ABBREVIATIONS}

AFA - Self-assessment of physical activity of children

TDT - Body Posture Test

BMI - Body Mass Index

WHO - World Health Organization

\section{CONFLICT OF INTEREST}

The authors of this paper have no conflicts of interest, including specific financial interests, relationships, and/or affiliations relevant to the subject matter or materials included.

\section{ACKNOWLEDGEMENT}

The authors wish to extend their appreciation to Professor Miloš P. Stojiljković and Professor Dubravko Bokonjić for his contribution to this paper that consisted in excellent design and statistical analysis.

\section{REFERENCES}

1. Van Balen LC, Dijkstra LJ, Hadders-Algra M. Development of postural adjustments during reaching in typically developing infants from 4 to 18 months. Exp Brain Res 2012; 220:109-19.

2. Windle RW. Posture and growth. Acta Physiother Rheumatol Belg 1954; 9:79-83.

3. Całka-Lizis T, Jankowicz-Szymańska A, Adamczyk K. Postawa ciała uczniów regularnie trenujących piłkę nożną na tle rówieoeników. Polish journal of sports medicine/medycyna sportowa 2008; 24:4.

4. Protic - Gava B, Krnjeta Ž. Postural status of children of early school age in four Districts of Vojvodina. Journal of Anthropological Society of Serbia, 2010; 45: 375-83.
5. Seefeldt V, Malina RM, Clark MA. Factors affecting levels of physical activity in adult. Sports Med 2002; 32:143-68.

6. Arem H, Moore SC, Patel A, et al. Leisure time physical activity and mortality: a detailed pooled analysis of the dose-response relationship. JAMA Intern Med 2015; 175: 959-67.

7. Brocklebank LA, Falconer CL, Page AS, Perry R, Cooper AR. Accelerometer-measured sedentary time and cardiometabolic biomarkers: a systematic review. Prev Med 2015; 76: 92-102.

8. Telama R, Yang X, Leskinen E, et al. Tracking of physical activity from early childhood through youth into adulthood. Med Sci Sports Exerc 2014; 46: 955-62.

9. Janssen I, Leblanc AG. Systematic review of the health benefits of physical activity and fitness in school-aged children and youth. Int J Behav Nutr Phys Act 2010; 7: 40 .

10. Iannotti RJ, Janssen I, Haug E, et al. Interrelationships of adolescent physical activity, screen-based sedentary behaviour, and social and psychological health. Int J Public Health 2009; 54: 191-8.

11. Prentice-Dunn H, Prentice-Dunn S. Physical activity, sedentary behavior, and childhood obesity: A review of cross-sectional studies. Psychol Health Med. Med 2012; 17: 255-73.

12. Leung MM, Agaronov A, Grytsenko K, Yeh MC. Intervening to reduce sedentary behaviors and childhood obesity among school-age youth: A systematic review of randomized trials. J Obes 2012; 2012: 685430 .

13. Omorou AY, Langlois J, Lecomte E, Briançon S, Vuillemin A. Cumulative and bidirectional association of physical activity and sedentary behaviour with health-related quality of life in adolescents. Qual Life Res 2016; 25: 1169-78.

14. Chen G, Ratcliffe J, Olds T, Magarey A, Jones M, Leslie E. BMI, health behaviors, and quality of life in children and adolescents: a school-based study. Pediatrics 2014; 133: e868-74.

15. Jandrić S. Differences between boys and girls in terms of physical activity. Facta Universitatis Series: Physical Education and Sport 2010; 8: 1-7.

16. Bjeković G, Tanović I, Pelemiš M. Korektivna gimnastika sa kineziterapijom. II dopunsko izdanje. Fakultet za fizičko vaspitanje i sport Istočno Sarajevo; Bijeljina: Grafosemberija 2011; 58-60.

17. Kaminsky L, ACM'S Health-Related Physical Fitness Assesment Manual. Third edition: Beograd: DATASTATUS; 2013. 40-1.

18. Nicklas TA, Baranowski T, Cullen KW, Berenson G. Eating patterns, dietary quality and obesity. J Am Coll Nutr 2001; 20: 599-608. 
19. Panasiuk L, Wdowiak L, Paprzycki P, Lukas W. Occurrence of overweight and obesity among adult rural population in Eastern Poland Relationship between obesity and selected socio-economic factors. Ann Agric Environ Med 2008; 15: 149-52.

20. Wojtyła A, Bojar I, Boyle P, Zatoński W, Marcinkowski JT, Biliński P. Nutritional behaviours among pregnant women from rural and urban environments in Poland. Ann Agric Environ Med 2011; 18: 169-74.

21. Jandrić SDj. Differences in postural disturbances between female adolescents handball players and nontraining peers. Vojnosanit Pregl 2016; 73: 337-42.

22. Medojević S, Jakšić D. Differences in postural disorders between boys and girls of 7-15 years of age at the territory of Vojvodina. In: Bala G, ed. Anthropological Status and physical activities of children, youth and adults. Novi Sad, Serbia: Faculty of sport and physical education, 2007: 49-54.

23. Jovović V, Čanjak R. Učestalost i struktura postularnih poremećaja kod učenika mlađeg adolescentnog doba u Crnoj Gori. Proceedings of the 3rd International Scientific Conference; 2011; Banja Luka, BiH: Proceedings Book 2012; 33.

24. World Health Organization Department of Nurtrition for Health and Development. WHO Child Growth Standards. Length/height-for-age, weight-for-age, weight-for-length, weight-for-height, and body mass indexfor-age. Methods and development. Geneva (Switzerland); 2006: 301-4.

25. Smith AJ, O’Sullivan PB, Beales DJ, de Klerk N, Straker LM.Trajectories of childhood body mass index are associated with adolescent sagittal standing posture. Int J Pediatr Obes 2011; 6: 97-106.

26. Latalski M, Bylina J, Fatyga M, et al. Risk factors of postural defects in children at school age. Ann Agric Environ Med2013; 20: 583-7.
27. Wyszyńska J, Podgórska-Bednarz J, Drzał-Grabiec J, et al. Analysis of relationship between the body mass composition and physical activity with bodyposture in children. BioMed Res Int 2016: 1851670.

28. Chinapaw MJM, Proper KI, Brug J, van Mechelen W, and Singh AS. Relationship between young peoples' sedentary behaviour and biomedical health indicators: a systematic review of prospective studies. Obes Rev 2011; 12: e621-32.

29. Brandalize M, Leite N. Orthopedic disorders in obese children and adolescents. Fisioter Mov 2010; 23:283-8. Portuguese

30. Martelli RC, Traebert J. Descriptive study of spinal postural changes in 10 to 16 year-old schoolchildren. Tangará-SC, 2004. Rev Bras Epidemiol 2006; 23: 283-8.

31. Santos CI, Cunha AB, Braga VP, et al. Occurrence of postural deviations in children of a school of Jaguariúna. São Paulo, Brazil. Rev Paul Pediatr 2009; 27: 74-80.

32. Do Espírito Santo A, Guimarães LV, Galera MF. Prevalence of idiopathic scoliosis and associated variables in schoolchildren of elementary public schools in Cuiabá, state of Mato Grosso, 2002. Rev Bras Epidemiol 2011; 14: 347-56.

33. Dumith SC, Gigante DP, Domingues MR, Kohl HW III. Physical activity change during adolescence: a systematic review and a pooled analysis. Int $\mathrm{J}$ Epidemiol 2011; 40: 685-98.

34. van Stralen MM, Yıldırım M, Wulp A, et al. Measured sedentary time and physical activity during the school day of European 10-to-12-year-old children: The ENERGY project. J Sci Med Sport 2014; 17: 201-6.

35. Verloigne M, Van Lippevelde W, Maes L, Yildirim M, Chinapaw M, Manios Y, De Bourdeaudhuij I. Levels of physical activity and sedentary time among 10- to 12-year-old boys and girls across 5 European countries using accelerometers: An observational study within the ENERGY-project. Int J Behav Nutr Phy Act 2012; 9: $34-41$. 